\title{
Jak być dobrym enaktywistą? Recenzja książki Daniela D. Hutto i Erika Myina Radicalizing Enactivism. Basic Minds without Content
}

Autorzy: Daniel D. Hutto i Erik Myin

Wydawca: The MIT Press

Data wydania: 2012

Liczba stron: 232

\section{Tomasz Komendziński}

Zakład Epistemologii i Kognitywistyki

Uniwersytet Mikołaja Kopernika w Toruniu

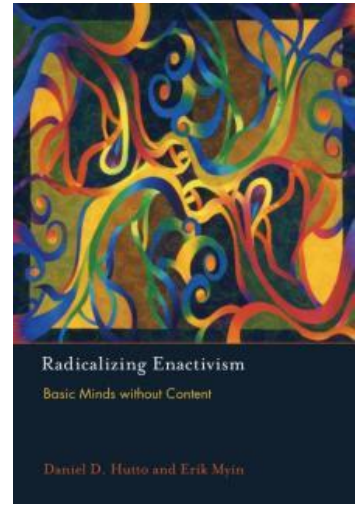
tkomen[]umk.pl

Przyjęto: grudzień 2013; zaakceptowano: luty 2014; opublikowano: lato 2014.

Pół wieku minęło od czasu, gdy w 1963 roku Paul Feyerabend pytał „How to Be a Good Empiricist?” i jednocześnie wzywał do tolerancji w kwestiach epistemologicznych („A Plea for Tolerance in Matters Epistemological” - to podtytuł pracy Feyerabenda). Dzisiaj Dan Hutto i Erik Myin w swej ostatniej książce zadają, jak się wydaje, podobne pytanie dotyczące enaktywizmu: „How to Be a Good Enactivist?”. Wzywają jednak do radykalizacji w kwestiach epistemologicznych, ogłaszając w podtytule, że basic minds są pozbawione content. Gdyby tę analogię pociągnąć dalej, to wypadałoby dodać, że płaszczyzną epistemologicznego sporu o empiryzm była filozofia nauki, zaś płaszczyzną dla radykalizacji enaktywizmu staje się filozofia umysłu. Filozofia umysłu szczególnej próby, bo z ducha Wittgensteina. Duch ten wyraźnie określa praktykę badawczą psychologii filozoficznej, w zakresie której lokuje się działalność badawcza Dana Hutto i Erika Myina. Nic więc dziwnego, że podstawowym zadaniem, jakie stawiają przed sobą, jest analiza konceptualna, która - jak się należy domyślać - ma doprowadzić do uporządkowania dokonań i postawienia nowych zadań. Z tego zadania, trzeba przyznać, Autorzy wywiązują się bardzo dobrze i jest to niewątpliwa korzyść wynikająca z lektury tej pracy. 
Analiza ta jest prowadzona wewnątrz każdego rozdziału i w perspektywie całego wywodu prowadzonego w książce.

W początkowych trzech rozdziałach Autorzy dokonują prezentacji trzech stanowisk, które ustalają topografię dla prowadzonej przez nich dyskusji oraz krytycznych analiz konceptualnych. Chodzi tu o przyjmowane przez Hutto i Myina REC (Radical Enactive (or Embodied) Cognition) oraz dwa stanowiska, wobec których Autorzy określają się: CIC (Content Involving Cognition) oraz CEC (Conservative Enactive (or Embodied) Cognition). CEC to stanowisko tych, którzy należą do twórców enaktywizmu (a wiec poczynając od Francisco Vareli, Evana Thompsona i Eleanor Rosch (1991)); przez Autorów zostają oni ulokowani gdzieś w połowie między CIC oraz REC. Niejako miarą tej odległości teoretycznej jest pogląd na temat kluczowych dla Hutto i Myina kwestii reprezentacji i treści umysłowych. Tutaj od razu można by zapytać o zasadność wyboru tej linii prowadzonych analiz wiodących do radykalizacji enaktywizmu. W rozdziałach 4-6 Autorzy dokonują obrony tego stanowiska, które topograficznie ustawili wobec CIC (jako bez treści) oraz wobec CEC (jako bez reprezentacji). W tym miejscu następuje szczegółowa analiza charakteru doświadczenia percepcyjnego i wprowadzenie maksymalnie minimalnego intelektualizmu, który dla REC jest do przyjęcia. W przedostatnim rozdziale Hutto i Myin pokazują, jak można bronić EMM (Extended Mind Hypothesis) przed zarzutami internalistów, zaś w ostatnim - jak radzić sobie z tak zwanym twardym problemem świadomości.

Całość wywodu stanowi doskonały pokaz analizy konceptualnej i spójnego stanowiska filozoficznego zakładającego przy tym - prawdopodobnie słusznie - że problem treści umysłowych jest kluczowy dla filozofii umysłu oraz filozofii kognitywistyki. Pytanie jednak jest innego rodzaju: czy przy takich rozstrzygnięciach filozoficznych z obszaru filozofii umysłu oraz filozofii kognitywistyki można w sposób skuteczny uprawiać kognitywistykę? Jeśli przypadkiem ujawniłaby się odpowiedź negatywna, wówczas podejrzane byłyby też analizy z zakresu filozofii tej kognitywistyki, a to $\mathrm{w}$ znaczeniu potrzeby ich przeprowadzenia przy innych motywacjach niż tylko intelektualna przyjemność i satysfakcja. W takich okolicznościach pytanie o zasadność radykalizacji enaktywizmu w znaczeniu Hutto i Myina staje się otwarte.

Wobec filozoficznych motywacji i jednoczesnych deklaracji wypowiadania się o kognitywistyce powstaje kolejne pytanie: czy przedstawiona propozycja radzi sobie z interdyscyplinarnością, w tym - z dyscyplinarną niejednorodnością kognitywistyki? Pytanie jest też bardziej ogólne: czy na poziomie filozofii (w tym przypadku - filozofii kognitywistyki) można sformułować program badawczy atrakcyjny, ważny i uzasadniony nie tylko na mocy tez filozoficznych. Stojąc wobec wyboru miedzy formułowaniem spójnego stanowiska filozoficznego (nawet jeśli jest ono z zakresu filozofii kognitywistyki, to pozostaje nadal stanowiskiem z wnętrza filozofii) a postawą badawczą (myślę tu o ba- 
daniach empirycznych) formułującą określony program badawczy, Autorzy zdecydowanie podjęli się formułowania stanowiska radykalnego enaktywizmu. Chodzi więc już nie tylko o odpowiedź na pytanie, „jak być dobrym enaktywistą”, w trybie rozstrzygnięć natury filozoficznej - tu dotyczących przede wszystkim basic minds oraz contents, ale również o wymierną ofertę badań interdyscyplinarnych (to ważne zagadnienie zawsze towarzyszące kognitywistyce, a dodatkowo tutaj - od początku towarzyszące formułowaniu i kształtowaniu się enaktywizmu, począwszy od momentu powstania książki napisanej przez neuronaukowca, filozofa i psychologa).

Jak zostać dobrym enaktywistą? Pierwsza odpowiedź namawia do takiego radykalizowania pewnego stanowiska (jak powiedzieliśmy: generalnie w zakresie filozofii psychologii, filozofii umysłu czy ostatecznie filozofii kognitywistyki), aby uzyskać stosunkowo precyzyjny i spójny pogląd zgodny z tezą o sprzężeniu ze środowiskiem umysłu ucieleśnionego i rozszerzonego, jednak bez wskazania na mechanizm tego sprzężenia, który poddawałby się sprawdzeniu. Dobrym enaktywistą można zatem zostać przez definicję czy z definicji. Szansa prowadzenia tu badań interdyscyplinarnych jest znikoma, a w najlepszym wypadku bardzo ograniczona.

Jaka jest alternatywna odpowiedź na pytanie o to, jak zostać dobrym enaktywistą? Alternatywna odpowiedź sugeruje drogę integracji propozycji enaktywistycznych (nie tylko filozoficznych) z poszukiwaniem wspólnego rdzenia łączącego je wszystkie. Sam jestem zwolennikiem takiego podejścia i budowania enaktywistycznego programu badawczego w oparciu o enaktywizm jako platformę badawczą. W ramach takiej platformy znajdą dla siebie miejsce nie tylko różniące się w szczegółach projekty (programy), ale również reprezentacje różnych dziedzin, czyniąc zadość interdyscyplinarności kognitywistyki i rozwijając ją, bo taka jest kolej rzeczy, o czym przekonuje historia kognitywistyki. Jest tam oczywiście także miejsce dla filozofii, ale na warunkach naukowych. Enaktywizm jako platforma badawcza formułowana jest częściowo na wzór znanego pomysłu Lakatosa odnośnie do programów badawczych, ale przy uznaniu, że zasada $4 \mathrm{E}^{70}$ jest tą, która określa jako twardy rdzeń platformę badawczą jako enaktywistyczną. To jest również element różniący pierwszą odpowiedź od drugiej. Zatem enaktywizm może należy nie tyle radykalizować, co integrować.

W ostatnim czasie argumentu do takiej postawy dostarczyła dyskusja, jaka miała miejsce przy okazji opublikowania artykułu w Behavioral and Brain Sciences na temat neuronauki drugoosobowej. W komentarzu „The brain as part of an enactive system” Shaun Gallagher, Daniel D. Hutto, Jan Slaby oraz

\footnotetext{
${ }^{70}$ od: Embodied, Embedded, Extended, Enaction
} 
Jonathan Cole ${ }^{71}$ próbowali pokazać, że „brains are part of a system, along with eyes and face and hands and voice, and so on, that enactively anticipates and responds to its environment”, natomiast neuronauka oraz metody, jakimi się posługuje - zwłaszcza neuroobrazowanie - ogólnie biorąc, nie mogą mieć nic, a co najwyżej niewiele wspólnego $\mathrm{z}$ enaktywizmem. W odpowiedzi na ten komentarz Mikah Allen (2013), w dużym stopniu wychowanek Gallaghera, wyjaśnił pojawiające się nieporozumienie wynikające $z$ błędnego obrazu współczesnej neuronauki i jednocześnie wskazał na istotną własność działającego mózgu, mianowicie fakt jego predykcyjnego charakteru, co czyni jaśniejszym działanie antycypacji, o której wspomina Gallagher z Hutto, Slabym i Cole'm.

Nie chciałbym zakończyć tej recenzji okrzykiem: „Enaktywiści wszelkich rodzajów, łączcie się”. Chciałbym natomiast podkreślić, że dla interdyscyplinarnych przecież badań enaktywistycznych kluczową kwestią jest możliwość sformułowania programu badawczego, który wykorzystywałby możliwie duży potencjał badawczy, wspierając się na pewnym akceptowanym twardym rdzeniu. Wydaje się, że propozycja Dana Hutto i Erika Myina, choć znakomicie napisana i przeprowadzona z zachowaniem wszelkich zasad sztuki analizy konceptualnej, nie stanowi takiej oferty. „Basic Minds without Contents” nie są takim twardym rdzeniem dla zintegrowanych i interdyscyplinarnych badań enaktywistycznych w kognitywistyce.

\section{Literatura}

Allen, M. 2013. Enactive Bayesians? Response to "the brain as an enactive system" by Gallagher et al. Żródło: http://neuroconscience.com Dostęp: 18.12.2013.

Feyerabend, P. 1963. How to Be a Good Empiricist - A Plea for Tolerance in Matters Epistemological. B.H. Baumrin, red. Philosophy of Science. The Delaware Seminar, vol. 2. New York, London, Sydney: Interscience Publisher a division of John Wiley and Sons.

Hutto, D.D. i Myin, E. 2012. Radicalizing Enactivism. Basic Minds without Content. The MIT Press.

Schilbach, L., Timmermans, B., Vogeley, K., Reddy, V., Costall, A., Bente, G. i Schlicht, T. 2013. Toward a Second-person Neuroscience. Behavioral and Brain Sciences, 36, 4: 421-422.

Varela, F. Thompson, E. i Rosch, E. 1991. The Embodied Mind: Cognitive Science and Human Experience. MIT Press.

\footnotetext{
${ }^{71}$ Jest to komentarz do "Toward a Second-person Neuroscience" autorstwa Leonharda Schilbacha, Berta Timmermansa, Kaia Vogeleya, Vasudevi Reddy, Alana Costalla, Gary'ego Bente'a i Tobiasa Schlichta, zamieszczony wraz z tą pracą w Behavioral and Brain Sciences. 36, 4: 421-422.
} 